\title{
Multixenobiotic resistance in coelomocytes from three echinoderm species
}

\author{
Émilie Doussantousse ${ }^{1}$, Émilien Pelletier ${ }^{1, *}$, Lucie Beaulieu $^{2,3}$, \\ Louis-Charles Rainville ${ }^{1}$, Claude Belzile ${ }^{1}$ \\ ${ }^{1}$ Institut des Sciences de la Mer de Rimouski (ISMER), and 2 Département de Biologie, Chimie et Géographie, \\ Université du Québec à Rimouski, 310 Allée des Ursulines, Rimouski, Quebec G5L 3A1, Canada \\ ${ }^{3}$ Institute of Nutraceuticals and Functional Foods (INAF), Université Laval, 2440 Boulevard Hochelaga, Québec, \\ Quebec G1V 0A6, Canada
}

\begin{abstract}
Multixenobiotic resistance (MXR) proteins are known to be present in most living organisms, but only a few studies have been conducted on echinoderms and especially on their circulating cells, the coelomocytes. The objective of the present study was to investigate the presence of MXR activity in coelomocytes of the sea urchin Strongylocentrotus droebachiensis, the sea star Leptasterias polaris and the sea cucumber Cucumaria frondosa. Cells were exposed to fluorescent substrates $(1 \mu \mathrm{M}$ Rhodamine B [RB] or $0.5 \mu \mathrm{M}$ calcein-AM [CAM]), with or without inhibitors $(50 \mu \mathrm{M}$ verapamil [Ver], $5 \mu \mathrm{M}$ cyclosporin-A [CsA] and $5 \mu \mathrm{M}$ MK571 [MK]), and single-cell fluorescence was measured by flow cytometry. The combinations RB + CsA and RB + Ver induced a fluorescence increase in $S$. droebachiensis and L. polaris coelomocytes, as well as in $S$. droebachiensis vibratile cells. The combination RB + MK induced a fluorescence increase in S. droebachiensis and C. frondosa coelomocytes. Finally, the combination CAM + MK induced a fluorescence diminution in L. polaris coelomocytes and $S$. droebachiensis vibratile cells. This difference in fluorescence incorporation indicated an MXR-like activity in coelomocytes, probably due to the presence of a P-glycoprotein (Pgp) and a multidrug resistance-associated protein (MRP)-like transporter. Western blot analysis was also carried out (Ab C219 and Ab C9) in order to detect potential MXR proteins using anti-MXR antibodies. Both Pgp and MRP were detected, but could not be further discriminated. MXR activity was clearly demonstrated in coelomocytes of $S$. droebachiensis, L. polaris and C. frondosa, although the identity of proteins responsible for this activity needs to be confirmed.
\end{abstract}

KEY WORDS: Multixenobiotic resistance $\cdot$ MXR $\cdot$ Echinoderms $\cdot$ Coelomocytes $\cdot$ P-glycoprotein $\cdot$ Pgp $\cdot$ Multidrug resistance-associated proteins $\cdot$ MRPs

Resale or republication not permitted without written consent of the publisher

\section{INTRODUCTION}

The way in which organisms handle xenobiotics is of prime importance for their survival in the environment. One of the key cellular processes is biotransformation, a metabolic process facilitating the excretion of potentially toxic molecules. Located upstream and downstream to that process, multixenobiotic resistance (MXR) is part of a large 'cellular housekeeping system' that handles toxic molecules. This excretion mechanism is highly dependent upon non-specific trans- porters using ATP to expel toxic moieties and residues (Epel 1998). MXR proteins can transport a wide range of metabolites and xenobiotics through the cell membrane, resulting in a lower intracellular concentration of xenobiotics and thus a lower toxic potential, and play a key role in regulating cellular and tissue levels of toxic agents (Ambudkar et al. 1999). Several proteins are involved in xenobiotic resistance, but those most studied in an environmental context are the P-glycoproteins (Pgp) and proteins from the multidrug resistance-associated proteins (MRP) family. 
Pgp is known to be the primary active transporter of unmodified xenobiotics (Zaja et al. 2007), transporting mostly large and moderately hydrophobic cations (Litman et al. 2001). It is widely distributed in tissues and has a variety of physiological roles in healthy cells, such as lipid transport, intracellular cholesterol trafficking and the cytotoxic activity of NK and T cells (Johnstone et al. 2000). Among the family of MRPs, MRP1 facilitates the extrusion of numerous glutathione, glucuronate and sulphate conjugates. MRP1 is a ubiquitous protein taking part in various physiological functions including defence against xenobiotics and endogenous toxic metabolites, leukotrienemediated inflammatory responses, as well as protection from the toxic effect of oxidative stress (Bakos \& Homolya 2007).

A combination of substrates and inhibitors is often used to indicate MXR activity (Neyfakh 1988, Cornwall et al. 1995, Marin et al. 2004). Since some substrates and inhibitors are more specific to one MXR protein than to another, it is sometimes possible to discriminate the proteins involved. For example, Rhodamine B (RB) is often used as a Pgp substrate (Minier \& Moore 1996, Reungpatthanaphong et al. 2003, Zaja et al. 2006) and a similar molecule, Rhodamine 123, is used as a Pgp- and MRP-like substrate (Hollo et al. 1996, Daoud et al. 2000). Calcein-AM (CAM) is also known as a substrate for both Pgp-like and MRP-like proteins, but calcein, its fluorescent hydrolysis product, is only a substrate for MRP-like transporters (Hollo et al. 1996, Essodaïgui et al. 1998). Among the inhibitors, cyclosporin-A (CsA) is a competitive Pgp inhibitor interacting with the activity site of Vinca alkaloids (Tamai \& Safa 1990, Saeki et al. 1993). Specifically, CsA is an ATPase inhibitor and induces the perturbation of substrate recognition (Ambudkar et al. 1999). The verapamil (Ver) involvement in drug resistance has also been known for a long time (Willingham et al. 1986). Ver stimulates Pgp ATPase activity (M. Müller et al. 1996), as it is transported by Pgp proteins (Romsicki \& Sharom 1999). Although it plays the role of a substrate, Ver is considered an inhibitor as it rapidly re-enters the cell after being exported and can, thus, effectively compete with the export of other endogenous or exogenous substrates (Eytan et al. 1996). Although CsA and Ver are not fully specific inhibitors of Pgp, as they also interact with MRP1 at micromolar concentrations (Haimeur et al. 2004), they are still widely used as reference compounds to detect Pgp activity (Kagan et al. 2010). The last inhibitor to be used in this study was MK571 (MK), a leukotriene $\mathrm{D}_{4}$ receptor antagonist and itself a glutathione conjugate. MK is the best example of a class of modulators that are generally specific to MRP-related transporters, but not to a certain MRP (Haimeur et al. 2004).
The drug resistance phenomenon has been known for a long time in cancer research (Kessel et al. 1968, Biedler et al. 1975, Foxwell et al. 1989). Drug resistance in some cases of cancer is caused by the overexpression of one or several proteins, leading to the failure of chemotherapy. The main drug resistance proteins are Pgp, the MRP family and breast cancer resistance proteins (BCRPs) (Haimeur et al. 2004). These proteins are also present in healthy cells, and the resistance mechanism is widespread among mammals (Johnstone et al. 2000), but also in fish (Hemmer et al. 1995), insects (Dressen et al. 1988), molluscs and worms (Holland Toomey \& Epel 1993, Cornwall et al. 1995, Köhler et al. 1998), echinoderms (Hamdoun et al. 2004), as well as in vascular plants and unicellular algae (Dudler \& Hertig 1992, Scherer et al. 2008). From an evolutionary perspective, Pgp and MRPs are well preserved (Minier et al. 1999, Bard 2000). MRPs only have a $15 \%$ amino acid homology with Pgp (Smital et al. 2004).

Major MRP activity and minor Pgp activity were observed in the fertilized eggs and embryos of the sea urchin Lytechinus anamesus, where electrophoresis analysis revealed 2 genes coding for reference proteins similar to human MRPs (Hamdoun et al. 2004). To our knowledge, this is the only documented mention of a MXR mechanism in an echinoderm species.

Echinoderms occupy a special place in evolution, and they remain enigmatic, even with recent progress in the study of species evolution (Smith 2008). Based on their embryonic development features, they are deuterostomes like the chordates, but their evolutionary paths have been distinct for hundreds of millions of years. Echinoderms are mostly stenohaline organisms and are found at all depths and salinities. The species studied here are common in the estuary and in the gulf of the St. Lawrence River, Canada: the green sea urchin Strongylocentrotus droebachiensis (class of echinoids), the 6-armed sea star Leptasterias polaris (class of asteroids) and the common sea cucumber Cucumaria frondosa (class of holothurians). There is limited information on the way echinoderms handle xenobiotics and on the role of their coelomocytes. The aim of the present study was to investigate the presence of a MXR-like mechanism in echinoderms living in a northern cold environment, as year-round low temperatures may induce particular behaviours. The search for MXR proteins has been conducted in coelomocytes sampled from adult organisms. Most echinoderms have large and extensive body cavities filled with coelomic fluid and circulating coelomocytes. At least 6 types of coelomocytes have been identified, but all types are not present in all species (Chia \& Xing 1996), not even in all specimens of the same species from the same environment (Xing et al. 2008). Most 
coelomocytes are classified as either phagocytes (or amoebocytes), spherule cells, progenitor cells, haemocytes, vibratile cells or crystal cells. Coelomocytes are of prime importance for echinoderms, as they are responsible for the immune system, clot formation, transport of nutrients, gas exchange, nutrient storage, graft rejection, and clumping and encapsulation of foreign bodies (Edds 1993).

\section{MATERIALS AND METHODS}

Animals and sampling coelomocytes. Echinoderms (Leptasterias polaris, Strongylocentrotus droebachiensis, Cucumaria frondosa) were sampled in St. Lawrence Estuary and kept in flow-through tanks for the summer (June to mid-October) at the ISMER aquaculture laboratory (Rimouski, Quebec, Canada). L. polaris and $S$. droebachiensis were fed ad libitum twice a week with Mytilus sp. and Laminaria sp., respectively, whereas a cocktail of microalgae (Pavlova sp., Isochrysis sp. and Nannochloropsis sp.) was given to $C$. frondosa. The water temperature varied from 0 to $12^{\circ} \mathrm{C}$, following seasonal conditions, and salinity was nearly constant at 31 .

Coelomic fluid containing coelomocytes was withdrawn $(2.5 \mathrm{ml})$ into a $5 \mathrm{ml}$ syringe (calibre 23 ) half preloaded with ice-cold calcium- and magnesium-free artificial sea water containing 50 mM EDTA (Békri \& Pelletier 2004). Coelomic fluid portions from 9 organisms (with no sex distinction) were pooled to avoid inter-individual variability and to obtain enough cells for each experiment. Samples were always obtained in the morning to minimize daily physiological variation, and all experiments were repeated 3 times (i.e. 3 different pools of coelomic fluid were used for each treatment). Coelomic fluid was filtered on a $40 \mu \mathrm{m}$ cell nylon strainer from VWR Canlab to remove debris and agglomerated cells. The cell concentration was determined using a haemocytometer (Bright-Line, Neubauer) in light microscopy at $20 \times$ magnification.

Chemicals. CsA, RB, Ver, tetrazolium, 3-4, 5 dimethylthiazol-2,5 diphenyl tetrazolium bromide salt (MTT), DMSO and Coomassie blue (R-250) were purchased from Sigma-Aldrich. CAM was obtained from VWR Canlab. MK was obtained from Cayman Chemicals. Focus protease arrest and recombinant murine C10/CCL6 antibody were purchased from Biolynx. Human P-glycoprotein (Pgp/MDR1) membranes and mouse anti-MRP1 monoclonal antibody C9 were obtained from Pharmigen BD Biosciences. Mouse antiPgp monoclonal antibody C219 was obtained from Calbiochem (VWR). Standard ovalbumin was purchased from Fisher-Scientific. MK, CAM and CsA stock solutions were prepared in DMSO. Final DMSO concentrations never exceeded $0.01 \%$. Sea water from the aquaculture laboratory was filtered through $0.2 \mu \mathrm{m}$ mesh to obtain filtered sea water (FSW) conserved at $4^{\circ} \mathrm{C}$ for a maximum of $5 \mathrm{~d}$. MTT solution was prepared in FSW.

Cytotoxicity test. Cytotoxicity of reagents was tested with the microculture tetrazolium MTT assay, which is a first choice for assessing the viability of adherent cells (Lindl et al. 2005) like coelomocytes. The yellow tetrazolium MTT is reduced by metabolically active cells, in part by the action of dehydrogenase enzymes, to generate the reducing equivalents of purple formazan. The method was adapted for coelomocytes according to the protocol developed for blue mussel haemocytes (Marin et al. 2004).

Coelomocytes were exposed to 3 concentrations of CAM (or RB) with or without inhibitors (Ver, CsA, or $\mathrm{MK})$ to test the cell toxicity of these treatments. Cells (600000) were deposited on a 96-well microplate $\left(12\right.$ wells treatment $^{-1}$ ) for $1 \mathrm{~h}$ at $10^{\circ} \mathrm{C}$ in the dark. Free cells were washed out by aspiration of overlaying coelomic fluid, and only adhered cells were exposed for $2 \mathrm{~h}$ to substrate solution with or without inhibitors in FSW. Substrates and inhibitors were then removed, and wells were rinsed with FSW. Wells were filled with MTT solution in FSW (final concentration $0.5 \mathrm{mg} \mathrm{ml}^{-1}$ ) for $2 \mathrm{~h}$ at $10^{\circ} \mathrm{C}$. MTT solution was washed out with FSW, and DMSO was added to wells to dissolve formazan crystals formed in adhering cells (Twentyman \& Luscombe 1987). Absorbance was recorded with Spectrafluor Plus microplate spectrometer (Tecan). The ratio between absorbance measured at 535 and $700 \mathrm{~nm}$ was used as a measure of cell viability, to avoid variability due to medium quenching and background level from a variation of the number of cells in each well (Supino 1995).

MXR assay. Determination of MXR activity is based on the use of model MXR inhibitors and substrates. The choice of substrates and inhibitors was made according to their affinities for MXR-like proteins, as previously reported by many authors (Essodaïgui et al. 1998, Litman et al. 2001, Haimeur et al. 2004). RB and CAM were used as model substrates, each in combination with 3 inhibitors: Ver, MK and CsA. Based on results of the cytotoxicity tests described above, the RB concentration was $1 \mu \mathrm{M}$ and the CAM concentration was $0.5 \mu \mathrm{M}$. Inhibitor concentrations were $50 \mu \mathrm{M}$ for Ver and $5 \mu \mathrm{M}$ for CsA and MK. Cells were exposed for $2 \mathrm{~h}$ to substrates with or without inhibitors (total $3 \mathrm{ml}$ ) in the dark and in FSW, before individual cell fluorescence measurements were carried out by flow cytometry (FCM). Treatments were done in triplicate, and each experiment was repeated 3 times.

Dose-response curves were obtained for the inhibitors and the transport of substrates. For the inhibition of transport, the substrate concentration was fixed 
at $1 \mu \mathrm{M}$ for RB and at $0.5 \mu \mathrm{M}$ for CAM. The concentration of each inhibitor ranged between 0 and $10 \mu \mathrm{M}$. No inhibitor was used for the transport of substrates. The substrate concentration was between 0 and $1 \mu \mathrm{M}$ for CAM and between 0 and 4 for RB. The MXR activity measurement was as described above, done in triplicate for each combination. Only Leptasterias polaris and Strongylocentrotus droebachiensis were used for the dose-response work.

FCM. Single-cell fluorescence was measured by FCM; $1.9 \mu \mathrm{m}$ Fluoresbrite beads (Polysciences) were added to each tube as an internal standard. Cells were analyzed with an Epics Altra flow cytometer (Beckman Coulter) fitted with a $488 \mathrm{~nm}$ laser operated at $15 \mathrm{~mW}$. The fluorescence of MXR substrates was measured at $525 \pm 20 \mathrm{~nm}$ for CAM and at $575 \pm 20 \mathrm{~nm}$ for RB. The data were analyzed using Expo32 v. 1.2b software (Beckman Coulter). Forward scatter (FS) versus side scatter (SS) plots were used to identify coelomocyte types (see Fig. 1). The average fluorescence of cells with FS and SS signals typical of healthy cells was measured and expressed relative to the fluorescence of the Fluoresbrite beads. The measured cell fluorescence was corrected by subtracting the natural autofluorescence of cells measured without CAM or RB addition; this auto-fluorescence represented between 0.05 and $18 \%$ of the fluorescence of the stained cells, but generally $<10 \%$.

Light and epifluorescence microscopy. The concentration of fluorescing calcein inside organelles in Leptasterias polaris coelomocytes (see 'Discussion: Calcein incorporation') was verified by epifluorescence microscopy. Coelomocytes were exposed to $0.5 \mu \mathrm{M}$ CAM with and without $\mathrm{MK}$ for $3 \mathrm{~h}$ in the dark at $10^{\circ} \mathrm{C}$. Differential interference contrast (DIC) and epifluorescence (Ex 450-490, Em BP 515-565) images were acquired with an Axio Observer Z1 inverted microscope (Carl Zeiss) fitted with an AxioCam MRc5 color camera.

Total proteins analysis, SDS-PAGE and Western blot analysis. After counting cells, coelomic fluid was centrifuged at $500 \times g$ for $8 \mathrm{~min}$ at $4^{\circ} \mathrm{C}$. Pelleted cells were resuspended in $9 \mathrm{ml}$ Tris buffer $(250 \mathrm{mM}, \mathrm{pH} 7$, and filtered onto $0.2 \mu \mathrm{m}$ membrane) containing $1 \%$ focus protease arrest. Cells were disrupted by brief sonication, followed by centrifugation at $14000 \times g$ for $30 \mathrm{~min}$ at $4^{\circ} \mathrm{C}$. Supernatant was conserved, and total proteins were determined using the Coomassie Plus protein assay kit from Pierce (Thermo Scientific). Bovine serum albumin (BSA) was used as the standard (Fraction V, Thermo Scientific). All samples were stored at $-40^{\circ} \mathrm{C}$ until analysis.

Samples were subjected to SDS-PAGE electrophoretic transfer to nitrocellulose and to immunoblotting procedures for the detection of Pgp/MDR1 and MRP1. Haemocyte samples from Mytilus sp. were used as a positive control, since Pgp activity has been demonstrated in these cells (Marin et al. 2004). Pgp/MDR1 membranes and recombinant murine C10 (MRP1) were used as positive controls, while ovalbumin $(0.2 \mu \mathrm{g})$ was used as a negative control. SDS-PAGE was performed under reducing conditions using NUPAGE 4 to $12 \%$ bis-Tris precast gels (Invitrogen) on a X-Cell Sure Lock Mini Cell system (Invitrogen). Of the total proteins, 1 and $3 \mu \mathrm{g}$ were loaded on the gel for each sample. The protein bands were visualized by silver staining (Silver Staining Plus kit, Bio-Rad). Following electrophoresis, proteins were transferred to a polyvinylidene fluoride membrane (PVDF; Bio-Rad) at $130 \mathrm{~mA}$ for $60 \mathrm{~min}$ using transfer buffer (Invitrogen) with the Xcell II blot module. The membrane was blocked overnight at $4{ }^{\circ} \mathrm{C}$ with $3 \%$ non-fat dry milk phosphate-buffered saline (PBS) solution from an Amplified Opti-4CN Detection Kit (Bio-Rad). After 2 washes with $0.1 \%$ Tween-20 in PBS (PBST), the membrane was incubated for $1 \mathrm{~h}$ at ambient temperature with mouse anti-Pgp monoclonal antibody C219 $\left(146 \mu \mathrm{g} \mathrm{ml}^{-1}\right)$ or mouse anti-MRP1 monoclonal antibody C9 $\left(250 \mu \mathrm{g} \mathrm{ml}^{-1}\right)$ in PBST-BSA $1 \%$ solution. Each antibody recognizes a preserved sequence. C219 recognizes the sequences VQEALD and VQAALD (Calbiochem, VWR), and C9 particularly recognizes the amino acid sequence between 864 and 952 (Pharmigen BD Biosciences). After 4 washes with PBST, the membrane was incubated for $1 \mathrm{~h}$ at ambient temperature with a goat anti-mouse-IgG-HRP Amplified Opti$4 \mathrm{CN}$ Detection Kit (Bio-Rad) in PBST-BSA $1 \%$ (dilution 10000 times). After a few washes with PBST, the membrane was incubated with Streptavidin-HRP (Bio-Rad) in PBST-BSA $1 \%$ solution. Color was detected according to the Opti-4CN Detection Kit protocol (Bio-Rad). Pictures were taken with an Alpha-Digidoc system from Alpha Innotech (Fisher Scientific).

Mass spectrometry (MS) analysis. For each sample, $14 \mu \mathrm{g}$ of total proteins were loaded on 2 gels for electrophoresis with the above conditions. On the first gel, the protein bands were visualized by Coomassie (G-250, Bio-Rad). On the second one, immunotransfer was done under the conditions described above. In order to obtain protein identification by mass spectrometry, bands of interest were excised from the gel using a scalpel, placed in an Eppendorf tube and stored in pure water. MS analysis was done using a proteomic platform by Centre génomique de Québec (Quebec, Canada). The excised protein spots were digested with trypsin using a MassPrep liquid handling robot (Waters) according to the manufacturer's specifications and the protocol by Shevchenko et al. (1996), with some modifications suggested by Havlis et al. (2003). Briefly, the excised spots were destained with $50 \mu \mathrm{l}$ of $50 \mathrm{mM}$ ammonium bicarbonate and $50 \mu \mathrm{l}$ 
acetonitrile, washed once with $50 \mu \mathrm{l}$ of $100 \mathrm{mM}$ ammonium bicarbonate and then dehydrated with $50 \mu \mathrm{l}$ of acetonitrile. The proteins were subsequently reduced in gel with $10 \mathrm{mM}$ DTT for $30 \mathrm{~min}$ at $37^{\circ} \mathrm{C}$ and alkylated with $55 \mathrm{mM}$ of iodoacetamide for $30 \mathrm{~min}$ at room temperature. Trypsin digestion was performed using $105 \mathrm{mM}$ of modified porcine trypsin (sequencing grade, Promega) at $58^{\circ} \mathrm{C}$ for $1 \mathrm{~h}$. The digested proteins were extracted twice, first with $30 \mu \mathrm{l}$ of $1 \%$ formic acid $/ 2 \%$ acetonitrile, followed by $12 \mu \mathrm{l} 1 \%$ formic acid/50\% acetonitrile.

The recovered peptide extracts were pooled, dried by vacuum centrifuge and resuspended in $5 \mu \mathrm{l}$ of $0.1 \%$ formic acid. Peptides were analyzed for protein identification by MS.

The digested protein samples were introduced into a tandem mass spectrometer, LTQ linear ion trap (ThermoFisher) equipped with a Thermo Surveyor MS pump (ThermoFisher) using a PicoFrit column BioBasic C18, with $10 \mathrm{~cm} \times 0.075 \mathrm{~mm}$ internal diameter (New

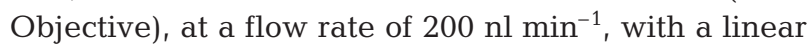
gradient from $2 \%$ acetonitrile in $0.1 \%$ formic acid to $50 \%$ acetonitrile in $0.1 \%$ formic acid over $30 \mathrm{~min}$. Tandem mass spectrometry (MS/MS) spectra were acquired by Xcalibur software Ver. 2.0 (ThermoFisher) using a data-dependent acquisition mode. The MS survey scan was 400 to $2000 \mathrm{~m} / \mathrm{z}$ and was followed by collision-induced dissociation of the 7 most intense ions for the LTQ. The internal parameter was set to $30 \mathrm{~s}$ for dynamic exclusion, and the relative collisional fragmentation energy was set to $35 \%$.

All MS/MS spectra were analyzed using Mascot v. 2.2.0 (Matrix Science) for peptide identification. Mascot was set up to search the Uniref100_12_7 Eukaryota_2759 database assuming the digestion enzyme trypsin. The following search criteria were used:
2 missed cleavages, the iodoacetamide derivative of cysteine was specified as a fixed modification and the oxidation of methionine was specified as a variable modification. Peptide tolerance was 2.0 Da for the precursor and 0.5 Da for MS/MS. The Mascot score corresponded to $10 \mathrm{x} \log (\mathrm{p})$, where $\mathrm{p}$ is the probability that the observed match with a given MS/MS spectra is a random event. A high score indicates identity of extensive sequence homology.

Statistical analysis. Data analysis and graphs were performed using SYSTAT 12 and SIGMAPLOT 10 (Systat Software). All data were analyzed by 2-way ANOVA (experiments $\times$ treatments). Homogeneity of variances was tested using 1-way ANOVA on the absolute value of residuals. The normality of residuals was tested using Lilliefors' test. If the conditions were not met, ANOVA was performed according to the nonparametrical approach suggested by Conover (1980). In this case, ANOVA was done on data transformed in rank (NP). To indicate a significant difference, $p$ must be $<0.01$. Post hoc Tukey's HSD was carried out.

\section{RESULTS}

\section{Cell distribution in coelomic fluid}

Not all coelomocyte types are present in all echinoderms, and their relative proportions may vary between species and with sampling periods. Only 1 population of coelomocytes was observed in Leptasterias polaris by FCM (Fig. 1A). This observation is consistent with previous reports (Kaneshiro \& Karp 1980), since the phagocytic amoebocytes are the most abundant of circulating coelomocytes in asteroids. Amoebocytes, red cells and small flagellated cells can be observed by
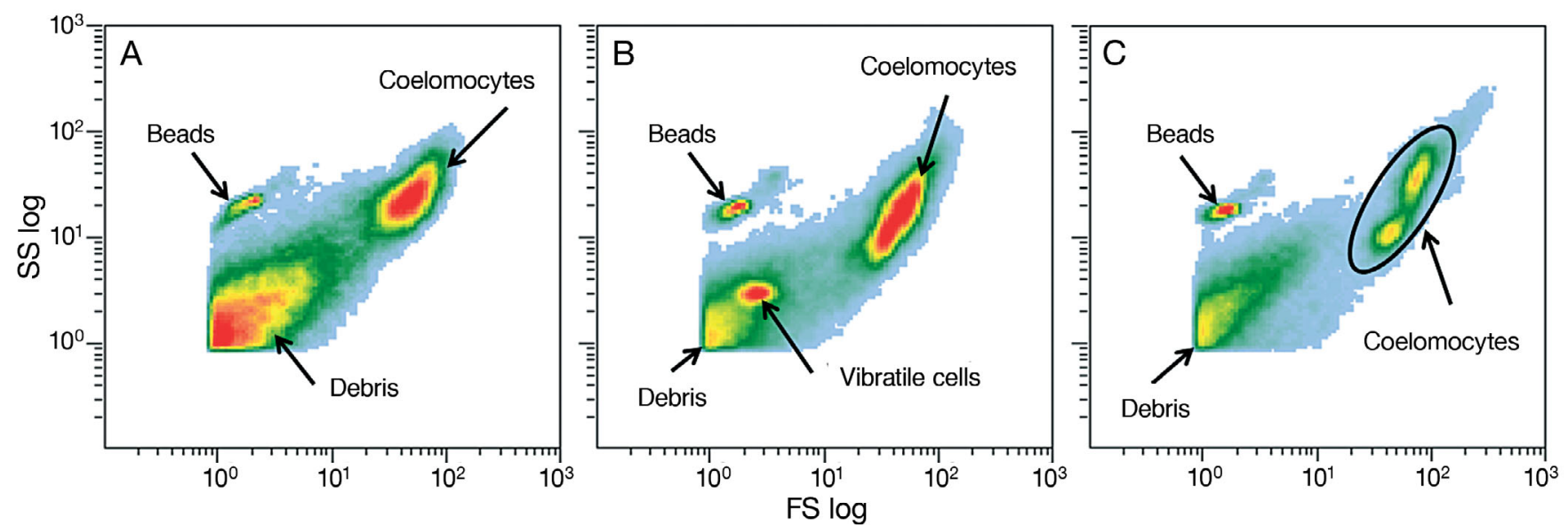

Fig. 1. Flow cytometric signature of the coelomocytes of (A) Leptasterias polaris, (B) Strongylocentrotus droebachiensis and (C) Cucumaria frondosa illustrated by density plots of forward scatter (FS) vs. side scatter (SS). Warmer colors represent regions with higher densitiy of cells 
light microscopy in Strongylocentrotus droebachiensis (data not shown), but only 2 populations of coelomocytes could be discriminated by FCM (Fig. 1B). We considered the small $S$. droebachiensis vibratile cells, as they are easy to distinguish from the other coelomocytes (Fig. 1B). Although several cell types are present in Cucumaria frondosa coelomic fluid (Noble 1970), only 1 general population of cells could be consistently discriminated and was considered to be coelomocytes (Fig. 1C).

\section{Cell viability}

RB $(1 \mu \mathrm{M})$, with or without inhibitors, had no effect on the viability of Strongylocentrotus droebachiensis or Leptasterias polaris coelomocytes, as measured by MTT (data not shown). CAM $(0.5 \mu \mathrm{M})$, with or without inhibitors, also had no effect on the viability of $S$. droebachiensis coelomocytes, as measured by MTT (data not shown). However, some combinations of CAM and inhibitors had a small, although statistically significant, effect on the viability of $L$. polaris coelomocytes $\left(\mathrm{p}<0.001 ; \mathrm{R}^{2}=0.491\right.$; Table 1$) ;$ CsA induced a decrease in viability at $10 \mu \mathrm{M}(\mathrm{p}=0.004)$ and $5 \mu \mathrm{M}$ $(p=0.004)$, and MK induced a viability decrease at $10 \mu \mathrm{M}(\mathrm{p}=0.007)$. The cell concentration in Cucumaria frondosa coelomic fluid was too low to carry out the microculture tetrazolium MTT assay. Taking into account the measured cell sensitivity and the concentrations commonly used in the literature, $50 \mu \mathrm{M}$ for Ver and $5 \mu \mathrm{M}$ for both $\mathrm{CsA}$ and $\mathrm{MK}$ were used in all experiments.

Table 1 . Toxicity of calcein-AM $\left(\mathrm{CAM}_{;} 0.5 \mu \mathrm{M}\right)$ on coelomocytes of Leptasterias polaris. Cells were incubated with $1 \mu \mathrm{M}$ substrate, with or without verapamil (Ver; 50, 30 and $10 \mu \mathrm{M}$ ), MK571 (MK; 10, 5 and $1 \mu \mathrm{M})$, or cyclosporin-A (CsA; 10, 5 and $1 \mu \mathrm{M})$. Cytotoxicity was measured with MTT in a microplate $\left(500000\right.$ cells) after $2 \mathrm{~h}$ in the dark at $10^{\circ} \mathrm{C}$. All values are means $( \pm \mathrm{SE}) .{ }^{*} \mathrm{p}<0.01$ when compared to the control (1-way A NOVA, Tukey post hoc); FSW: filtered sea water

\begin{tabular}{|lc|}
\hline Treatment & $\begin{array}{c}\text { Cell viability } \\
(535 / 700 \text { nm absorbance })\end{array}$ \\
\hline FSW & $2.47 \pm 0.07$ \\
CAM & $2.55 \pm 0.12$ \\
Ver 50 & $2.62 \pm 0.15$ \\
Ver 30 & $2.41 \pm 0.14$ \\
Ver 10 & $2.49 \pm 0.08$ \\
CsA 10* & $1.98 \pm 0.09^{*}$ \\
CsA 5* & $2.22 \pm 0.06^{*}$ \\
CsA 1 $10^{*}$ & $2.15 \pm 0.09$ \\
MK 5 & $1.95 \pm 0.06^{*}$ \\
MK 1 & $1.95 \pm 0.11$ \\
\end{tabular}

\section{Measurement of MXR-like activity by FCM}

$\mathrm{RB}$

Treatments with inhibitors induced an increase of fluorescence in Strongylocentrotus droebachiensis coelomocytes (NP-2-way ANOVA: $\mathrm{p}<0.001 ; \mathrm{R}^{2}=$ 0.911; Fig. 2A) and vibratile cells (NP-2-way ANOVA: $\mathrm{p}<0.001 ; \mathrm{R}^{2}=0.871$; Fig. 2C). All 3 inhibitors induced a significant fluorescence increase in S. droebachiensis coelomocytes $(\mathrm{p}<0.001, \mathrm{p}<0.001$ and $\mathrm{p}=0.003$, respectively), while only Ver and CsA induced an increase in vibratile cells (both $\mathrm{p}<0.001$ ).

Because there was significant interaction between experiments and treatments in Leptasterias polaris coelomocytes (NP-2-way ANOVA, experiments $\times$ treatments: $\left.p=0.004 ; R^{2}=0.834\right)$, data for different experiments are presented separately (Fig. 2B). Ver (Expt 1, post hoc Tukey: $\mathrm{p}=0.007$ ) and MK (Expt 2, post hoc Tukey: $p=0.002$ ) induced a significant increase of $\mathrm{RB}$ accumulation in one of the experiments. CsA induced an increase of RB accumulation in all experiments (Expts 1, 2 and 3, post hoc Tukey: p < $0.001, p=0.008$ and $p=0.002$, respectively).

A significant interaction between experiments and treatments was also observed in Cucumaria frondosa coelomocytes (2-way ANOVA, experiments $\times$ treatments: $\left.p=0.001 ; R^{2}=0.946\right)$, and data for different experiments are presented separately (Fig. 2D). Inhibitors induced an increase of RB accumulation, although not always in a statistically significant way. Ver induced a significant increase for 2 experiments (Expts 2 and 3, post hoc Tukey: both $\mathrm{p}<0.001$ ). MK induced a significant increase of RB accumulation for all experiments (Expts 1, 2 and 3, post hoc Tukey: all p < 0.001). CsA induced an increase for 1 experiment (Expt 3, post hoc Tukey: $\mathrm{p}<0.001$ ).

\section{CAM}

MK treatment had a significant effect on calcein fluorescence in Leptasterias polaris coelomocytes (2-way ANOVA: $\mathrm{p}<0.001 ; \mathrm{R}^{2}=0.683$ ) and Strongylocentrotus droebachiensis vibratile cells (NP-2-way ANOVA: $\mathrm{p}<$ 0.001; $R^{2}=0.792$ ) (Fig. 3B,C). MK induced a significant decrease of calcein accumulation in L. polaris coelomocytes (post hoc Tukey: p < 0.001; Fig. 3B) and $S$. droebachiensis vibratile cells (post hoc Tukey: $p<0.001$; Fig. 3C). None of the inhibitors had a significant effect on S. droebachiensis (2-way ANOVA: $\mathrm{p}<0.001 ; \mathrm{R}^{2}=$ 0.919; post hoc Tukey failed; Fig. 3A) or Cucumaria frondosa (2-way ANOVA: $\mathrm{p}=0.028$; Fig. 3D) coelomocytes, even if a decrease in fluorescence was apparent, but not significant, among definite criterion after 


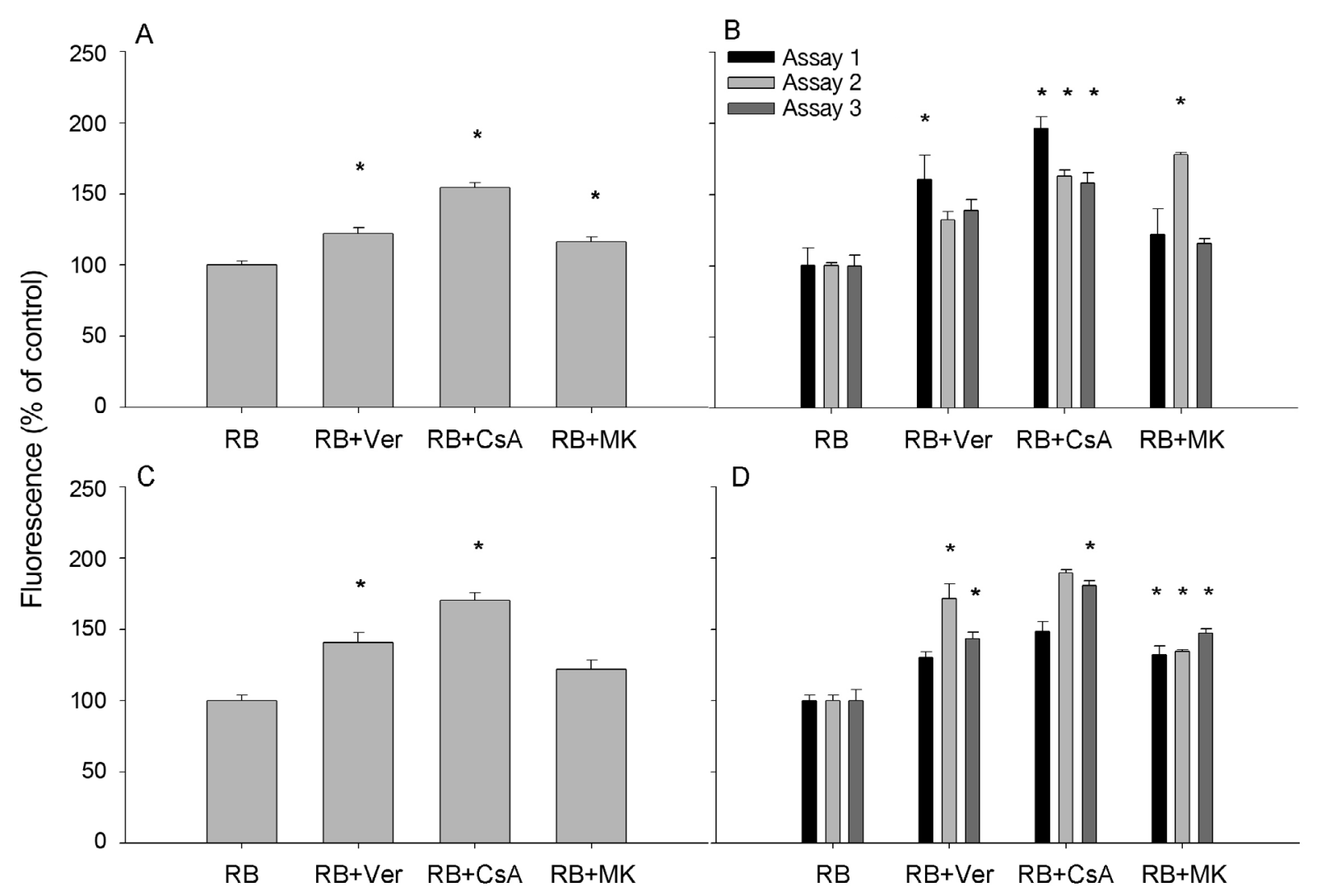

Fig. 2. Flow cytometric measurement of fluorescent Rhodamine B (RB) in (A) coelomocytes of Strongylocentrotus droebachiensis, (B) coelomocytes of Leptasterias polaris, (C) vibratile cells of S. droebachiensis and (D) coelomocytes of Cucumaria frondosa. Cells were incubated with $1 \mu \mathrm{M} R \mathrm{~B}$, with or without verapamil (Ver; $50 \mu \mathrm{M})$, cyclosporin-A $(\mathrm{CsA} ; \mu \mathrm{M})$, or MK571 (MK; $5 \mu \mathrm{M})$ $\left(\mathrm{RB}, \mathrm{RB}+\mathrm{Ver}, \mathrm{RB}+\mathrm{CsA}, \mathrm{RB}+\mathrm{MK}\right.$, respectively) for $3 \mathrm{~h}$ in the dark at $10^{\circ} \mathrm{C}$. $\mathrm{RB}$ alone was used as the control. Values are means $( \pm \mathrm{SE})$ of 3 separate assays in which the treatment was done in triplicate (Panels A \& $\mathrm{C}$; 2-way ANOVA, Tukey post hoc on treatments). Three separate assays were done, and values are means $( \pm \mathrm{SE})$ of triplicates of each treatment (Panels B \& $\mathrm{D}_{;}$2-way ANOVA, Tukey post hoc on experiment $\times$ treatments). ${ }^{*} \mathrm{p}<0.01$ when compared to the control

MK treatment on C. frondosa coelomocytes (post hoc Tukey: $\mathrm{p}=0.031$ ). The incorporation of CAM in L. polaris coelomocytes observed by epifluorescence microscopy revealed the presence of fluorescent granules inside the coelomocytes when the cells were treated with the inhibitor MK, but also in the absence of the inhibitor (Fig. 4).

\section{Dose-response measurements}

Dose-response curves for the inhibition of substrate transport and for the transport of substrates are shown in Fig. 5. The inhibitor treatments had a significant effect on substrate fluorescence in Leptasterias polaris coelomocytes (ANOVA: $\mathrm{p}<0.001 ; \mathrm{R}^{2}=0.823$; [MK, Fig. 5A] and $\mathrm{R}^{2}=0.848$ [CsA, Fig. 5B]). The MK concentrations of 5 and $10 \mu \mathrm{M}$ (Fig. 5A) induced a significant decrease of calcein accumulation in L. polaris coelomocytes (post hoc Tukey: $p=0.003$ and $p=0.001$, respectively). The action of the inhibitors on substrate accumulation in L. polaris coelomocytes is described by a hyperbolic decay for MK $\left(p<0.0001 ; R^{2}=0.941\right)$ and CsA $\left(p<0.001 ; R^{2}=0.876\right)$. CsA concentrations of 5 and $10 \mu \mathrm{M}$ (Fig. 5B) induced a significant increase of RB accumulation in L. polaris (post hoc Tukey: $p=0.006$ and $p=0.01$, respectively). The MK treatment showed no statistically significant effect on CAM accumulation in Strongylocentrotus droebachiensis coelomocytes (ANOVA: $p=0.038 ; \mathrm{R}^{2}=0.607$; Fig. 5A). In addition, the CsA treatment had no significant effect on $R B$ accumulation $\left(p=0.026 ; R^{2}=0.639\right.$; Fig. $5 \mathrm{~B})$. Even though no statistical differences were demonstrated by ANOVA in $S$. droebachiensis, a clear tendency could be observed. Indeed, the action of the inhibitors on substrate accumulation was described by a hyperbolic decay for $\mathrm{MK}\left(\mathrm{p}<0.01 ; \mathrm{R}^{2}=0.743\right)$ and a hyperbolic increase for CsA ( $\left.<<0.01 ; \mathrm{R}^{2}=0.769\right)$ in $S$. droebachiensis coelomocytes. No vibratile cells were observed in $S$. droebachiensis coelomic fluid on the day of this experiment. CAM transport (Fig. 5C) was described 

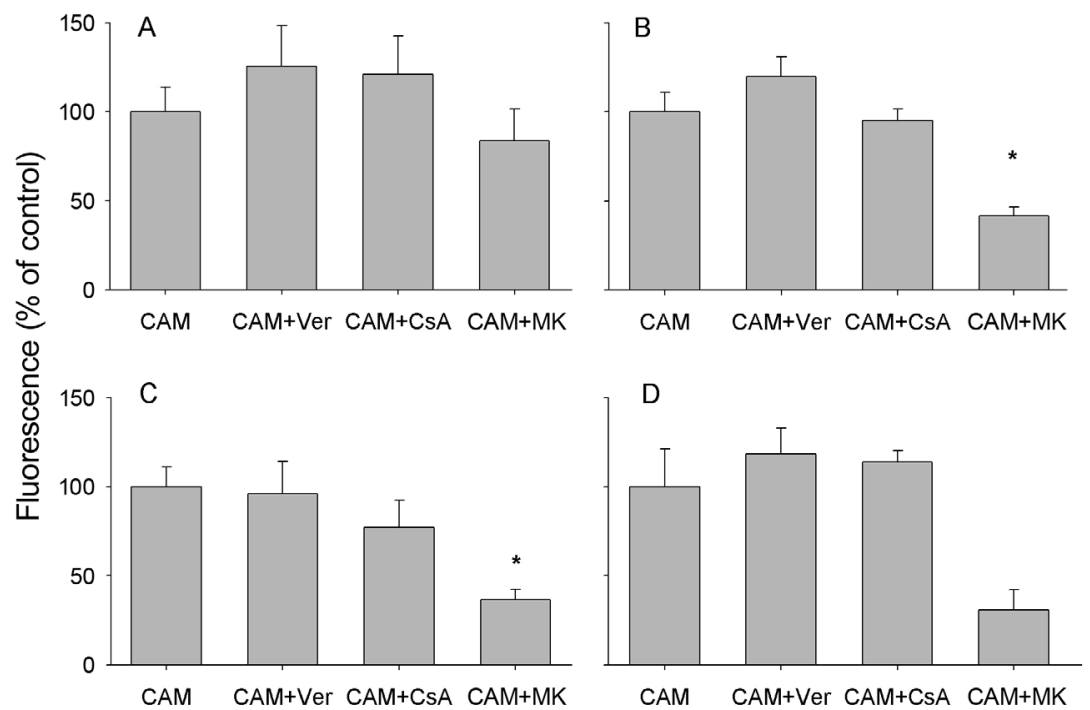

Fig. 3. Flow cytometric measurement of fluorescent calcein in (A) coelomocytes of Strongylocentrotus droebachiensis, (B) coelomocytes of Leptasterias polaris, (C) vibratile cells of $S$. droebachiensis and (D) coelomocytes of Cucumaria frondosa. Cells were incubated with $0.5 \mu \mathrm{M}$ calcein-AM (CAM), with or without verapamil (Ver; $50 \mu \mathrm{M})$, cyclosporin-A $\left(\mathrm{CsA}_{;} 5 \mu \mathrm{M}\right)$, or MK571 (MK; $5 \mu \mathrm{M})(\mathrm{CAM}, \mathrm{CAM}+\mathrm{Ver}, \mathrm{CAM}+\mathrm{CsA}, \mathrm{CAM}+\mathrm{MK}$, respectively) after $3 \mathrm{~h}$ in the dark at $10^{\circ} \mathrm{C}$. CAM alone was used as the control. All values are means $( \pm \mathrm{SE})$ of 3 separate assays in which the treatment was done in triplicate. ${ }^{*} p<0.01$ when compared to the control; 2-way ANOVA, Tukey post hoc on treatments
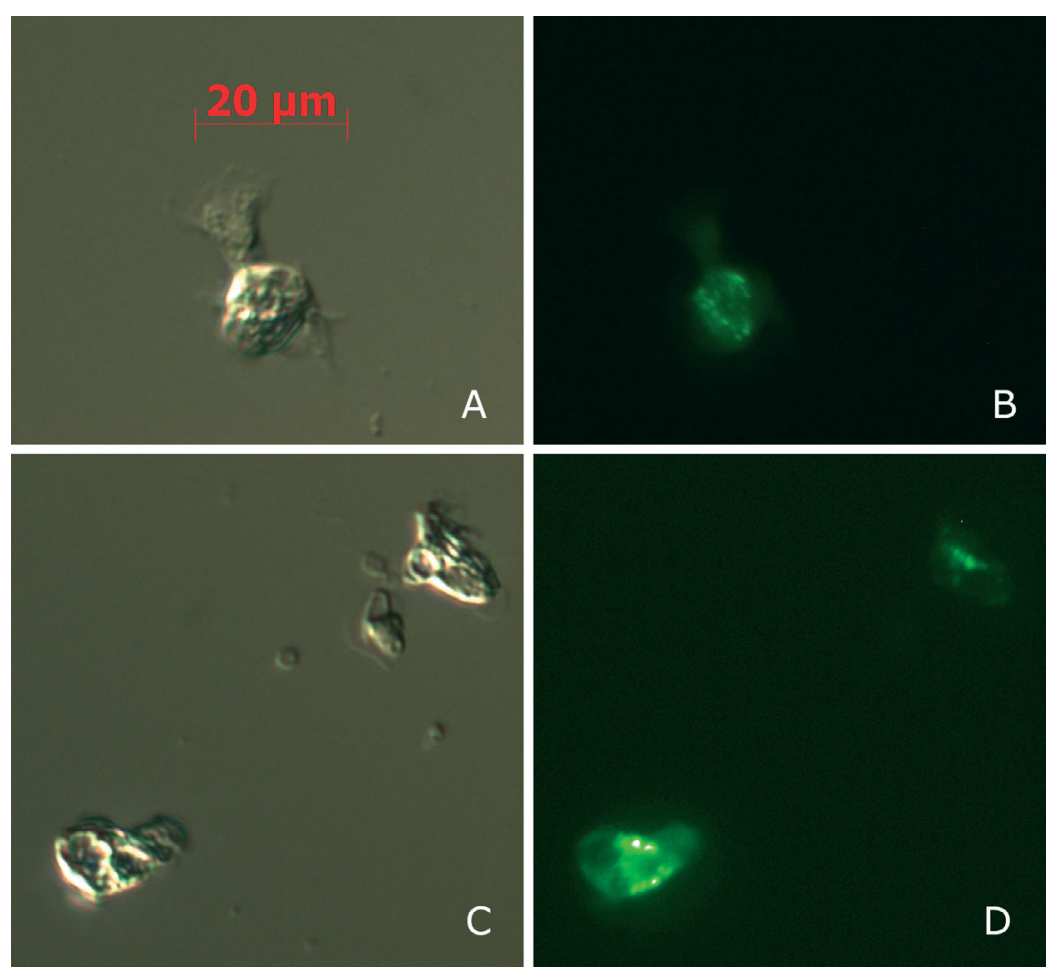

Fig. 4. Differential interference contrast and epifluorescence microscopy images of Leptasterias polaris coelomocytes incubated with $0.5 \mu \mathrm{M}$ calcein-AM without inhibitor $(A, B)$ and with the inhibitor MK571 $(\mathrm{C}, \mathrm{D})$ by a hyperbolic dose-response relationship in coelomocytes of both L. polaris $\left(\mathrm{p}<0.0001 ; \mathrm{R}^{2}=0.877\right)$ and $S$. droebachiensis $\left(\mathrm{p}<0.0001 ; \mathrm{R}^{2}=0.974\right)$. RB transport (Fig. 5D) was described by a linear dose-response relationship in coelomocytes of L. polaris ( $\mathrm{p}<0.0001$; $\left.\mathrm{R}^{2}=0.997\right)$ and $S$. droebachiensis $(\mathrm{p}<$ $\left.0.0001 ; R^{2}=0.987\right)$. The fluorescence of vibratile cells was too low to be include in this figure. The fluorescence of S. droebachiensis coelomocytes was always lower than that of L. polaris coelomocytes.

\section{Measurement of MXR-like proteins by SDS-PAGE and Western blot analysis}

Sample proteins were separated by SDS-PAGE and visualized by silver staining as well as by immunoblotting to detect the presence of MXR-like proteins (Figs. $6 \& 7$ ). The bands with a rapid and intense signal after staining of the PVDF membrane were associated with MXR-like proteins if their molecular weight corresponded to similar proteins analyzed in other animal species. The bands identified with an arrow in Figs. 6B \& 7B corresponded to these criteria.

As illustrated in Fig. 6A, silver staining highlighted many more proteins in echinoderm samples than in the bivalve Mytilus sp. Using the anti-MRP1 monoclonal antibody C9, 3 main protein bands were observed in echinoderm samples, while only 2 were visible in Mytilus sp. samples (Fig. 6B; indicated by arrows). The molecular weights of the 3 main protein bands in Strongylocentrotus droebachiensis were $>191$, 100 and $65 \mathrm{kDa}$, respectively. Comparatively, the stained bands were 190, 100 and $40 \mathrm{kDa}$ in Leptasterias polaris and Cucumaria frondosa extracts. In Mytilus sp., they were 100 and $40 \mathrm{kDa}$. The signal detected from the control recombinant murine $\mathrm{C} 10$ was weak (Fig. 6B; circled band).

Use of the C219 anti-MDR1 antibody allowed the detection of 3 main bands in echinoderms and 2 main 

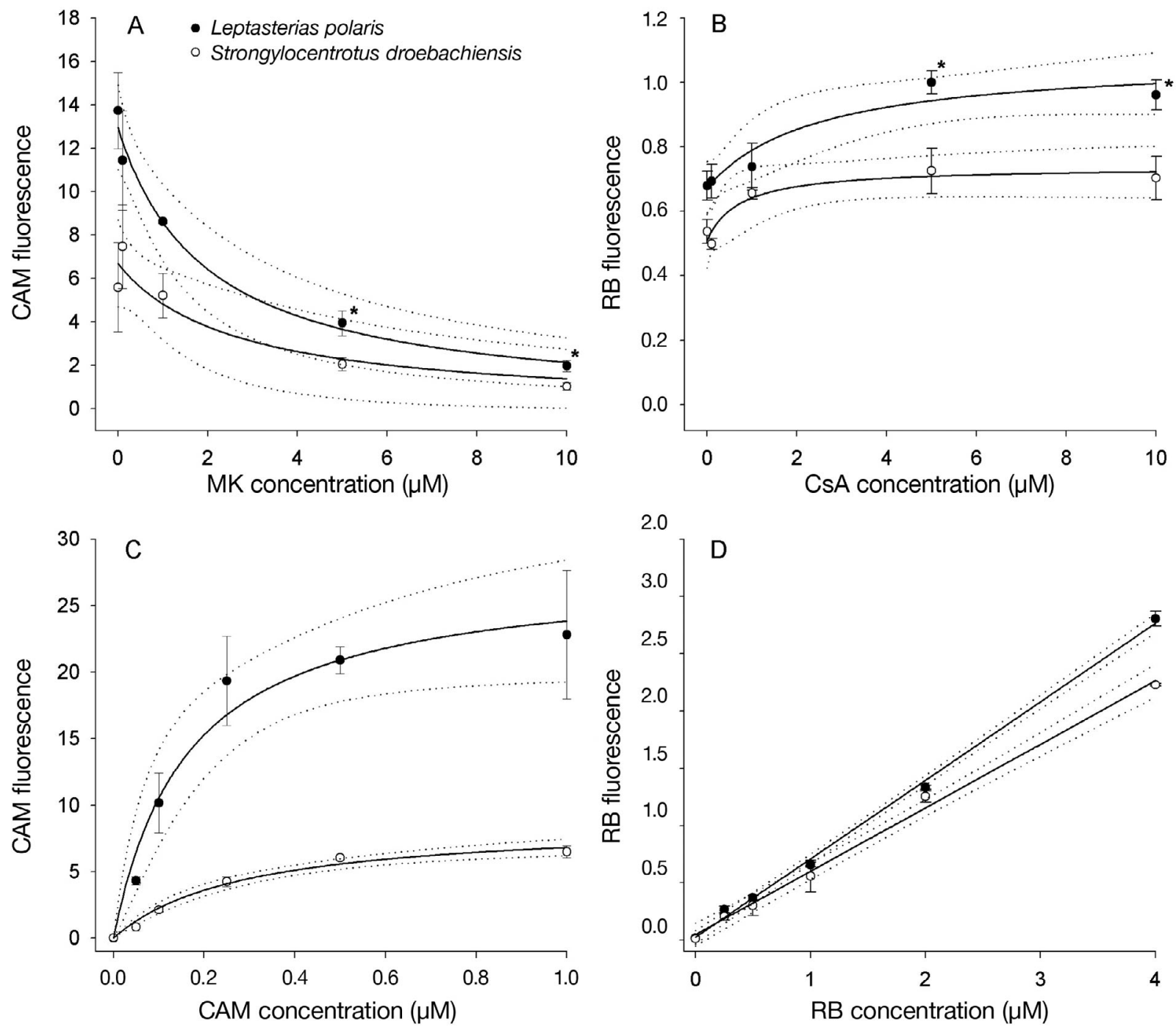

Fig. 5. Fluorescence measurements by flow cytometry of (A) $0.5 \mu \mathrm{M}$ calcein-AM (CAM) with a dose-response of MK571 (MK), (B) $1 \mu \mathrm{M}$ Rhodamine B (RB) with a dose-response of cyclosporin-A (CsA), (C) a dose-response of CAM and (D) a dose-response of RB. Cells were incubated for $2 \mathrm{~h}$ in the dark at $10^{\circ} \mathrm{C}$. Values are means $( \pm \mathrm{SE})$ of triplicate assays $(1$-way ANOVA: $\mathrm{p}<$ 0.01 ). ${ }^{*}$ indicate a statistical difference between the concentration and the zero of the dose-response curve (post hoc Tukey: $\mathrm{p}<0.01$ ). A regression curve (solid line) and its $95 \%$ confidence intervals (dotted lines) were drawn for each dose-response treatment

bands in Mytilus sp. (Fig. 7B; indicated with arrows). The observed bands have the same apparent mass as those detected using the anti-MRP1 antibody $(>191$, 100 and $65 \mathrm{kDa}$ for Strongylocentrotus droebachiensis; 190, 100 and $40 \mathrm{kDa}$ for Leptasterias polaris and Cucumaria frondosa). The same concordance between detected bands was observed in $M$. edulis. The 2 antibodies thus appear to have identified the same bands. In the positive control (human membrane preparation containing Pgp), the antibody C219 anti-MRP1 detected proteins of 100, 65 and 40 kDa (Fig. 7; Lane 2).

\section{Identification of MXR-like proteins by MS}

Several bands were analyzed by MS in order to identify MXR-like proteins in Strongylocentrotus droebachiensis (191, 170, 100 and $65 \mathrm{kDa})$, in Cucumaria frondosa $(191,170,100$ and $40 \mathrm{kDa})$ and in Leptasterias polaris $(170,100$ and $40 \mathrm{kDa})$. A protein that could be associated with the MXR/MDR family was found in S. droebachiensis extract from the $100 \mathrm{kDa}$ band. The molecular weight of this protein was $96 \mathrm{kDa}$ as established by MS/MS spectra using the Mascot program and it was attributed to a major vault protein (MVP) 
A

\section{B}

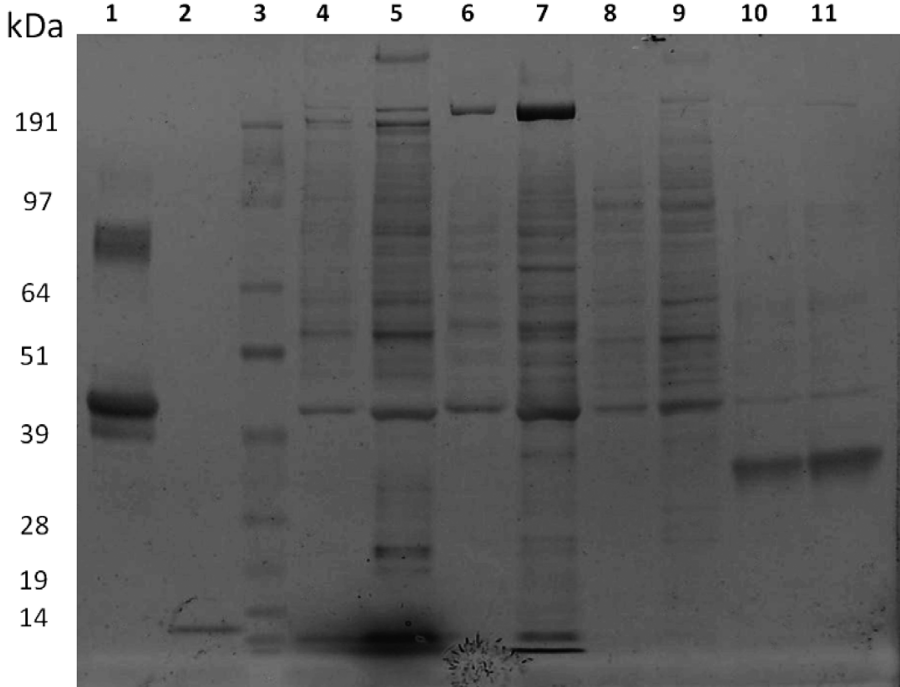

$\begin{array}{lll}1 & 2 & 3\end{array}$

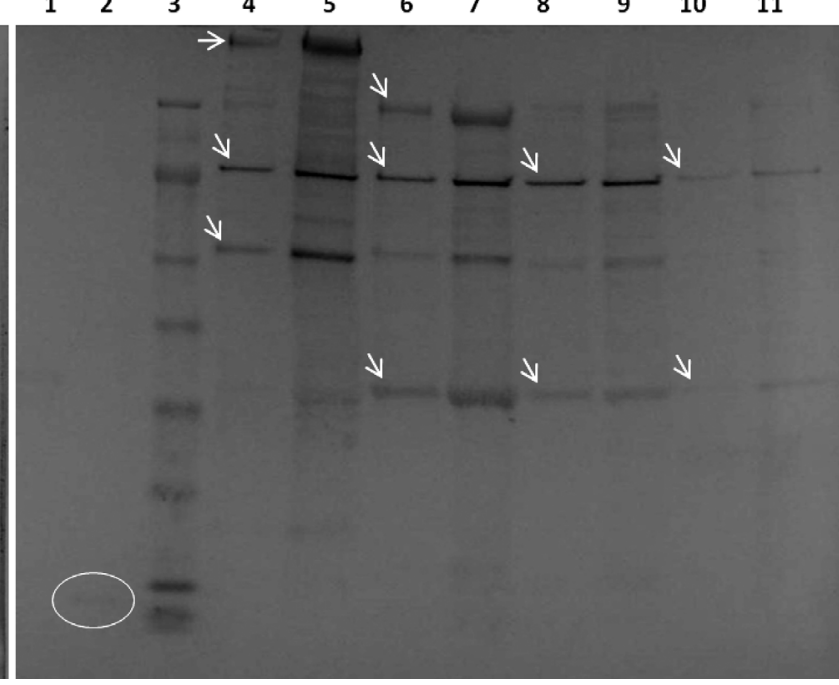

Fig. 6. (A) Silver-stained SDS-PAGE and (B) Western blot of coelomocyte extracts from echinoderms; the following lane descriptions apply to both. Lane 1: negative control protein ovalbumine (Fischer-Scientific); Lane 2: recombinant murine partial C10 (Biolynx); Lane 3: molecular weight standards SeeBlue Plus2, 4 to $250 \mathrm{kDa}$ (Invitrogen); Lanes 4 \& 5: 3 and 5 ug proteins from Strongylocentrotus droebachiensis coelomocyte extract; Lanes 6 \& $7: 3$ and $5 \mu \mathrm{g}$ proteins from Leptasterias polaris coelomocyte extract; Lanes 8 \& 9: 3 and $5 \mu \mathrm{g}$ proteins from Cucumaria frondosa coelomocyte extract: Lanes 10 \& 11: 3 and $5 \mu \mathrm{g}$ proteins from Mytilus edulis haemocyte extract. Panel B: the mouse monoclonal antibody C9 was used (BDBiosciences Pharmigen). The positive control reaction of multidrug resistance-associated proteins is circled, and the positive reactions of extracts with antibody are indicated by arrows

A

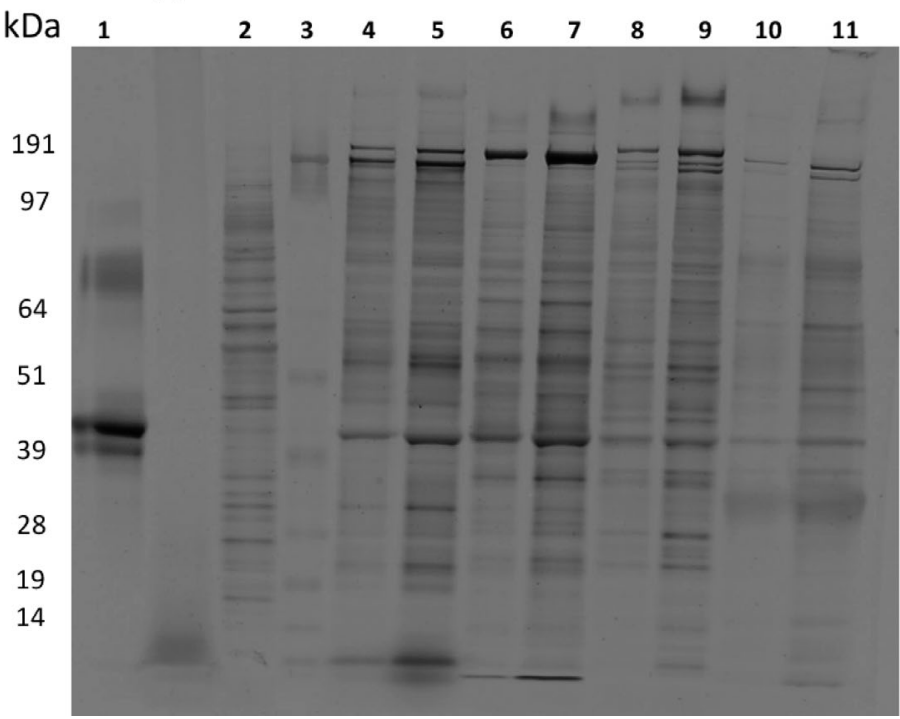

B

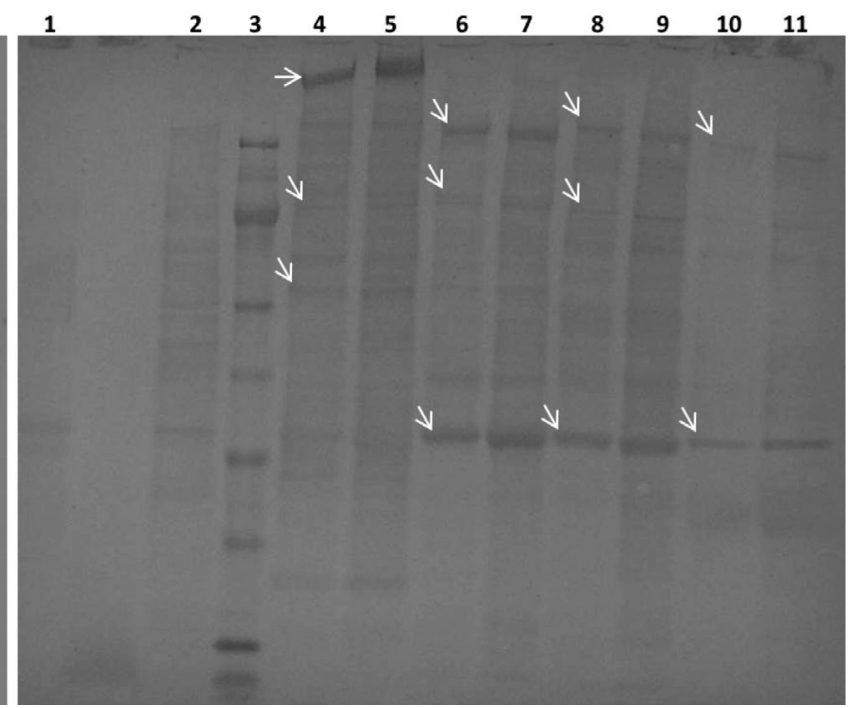

Fig. 7. (A) Silver-stained SDS-PAGE and (B) Western blot of coelomocyte extracts from echinoderms; the following lane descriptions apply to both. Lane 1: negative control protein ovalbumine (Fischer-Scientific); Lane 2: human membrane Pgp (BD Biosciences); Lane 3: molecular weight standards SeeBlue Plus2, 4 to $250 \mathrm{kDa}$ (Invitrogen); Lanes 4 \& 5: 3 and 5 ug proteins from Strongylocentrotus droebachiensis coelomocyte extract; Lanes 6 \& $7: 3$ and $5 \mu \mathrm{g}$ proteins from Leptasterias polaris coelomocyte extract; Lanes 8 \& 9: 3 and $5 \mu \mathrm{g}$ proteins from Cucumaria frondosa coelomocyte extract: Lanes 10 \& 11: 3 and $5 \mu \mathrm{g}$ proteins from Mytilus edulis haemocyte extract. Panel B: the mouse monoclonal antibody C219 was used (Calbiochem). The positive reactions of extracts with antibody are indicated by arrows 
from the sea urchin Strongylocentrotus purpuratus (Accession No. Q5EA1J7). The identification was made from 4 peptides (sequence coverage of $8.4 \%$ ) with a Mascot score of $100 \%$.

\section{DISCUSSION}

Coelomocytes play a crucial role in all echinoderm species, as their immune systems are dependent upon these circulating cells (Chia \& Xing 1996). The present work is the first comparative study of coelomocytes from 3 different echinoderm species using exactly the same protocol to assess MXR-like activity. Our study provides evidence of the presence of MXR activity in these coelomocytes, but the identity of the proteins needs to be confirmed by other techniques. Indeed, the coelomocytes showed MXR activity, as indicated by the effect of MXR inhibitors on the accumulation of model MXR substrates (measured by FCM). In addition, Western blot enabled the detection of potential MXR proteins using anti-MXR antibodies, even though the identity of the proteins could not be confirmed.

The presence of MXR proteins has already been reported in various invertebrates, including the sponge Suberites domuncula (W. Müller et al. 1996), the marine worm Urechis caupo (Holland Toomey \& Epel 1993), as well as in the haemocytes of freshwater (Zaja et al. 2006) and marine mussels (Minier \& Moore 1996, Marin et al. 2004). Even though there are several studies available on invertebrate MXR, only 1 study discussed MXR activity in an echinoderm. Indeed, MRPlike activity seems to be the major MXR activity in the eggs and embryos of the sea urchin Strongylocentrotus purpuratus, even if a low level of Pgp-like activity was revealed (Hamdoun et al. 2004).

\section{RB incorporation}

The presence of a MXR transporter was confirmed in coelomocytes of all studied echinoderms using RB as a model substrate. When MXR inhibitors were used, an increase of the fluorescence was noted, as previously reported for other species (Cornwall et al. 1995, Kerboeuf et al. 1999, Hamdoun et al. 2004, Marin et al. 2004, Zaja et al. 2006).

This observed MXR activity could be due to the presence of both Pgp-like and MRP-like proteins, since, as previously mentioned, RB is probably transported by both types of proteins. Regarding the specificity of inhibitors (Foxwell et al. 1989, Eytan et al. 1996, Ambudkar et al. 1999), the combination of RB with CsA and Ver could highlight a Pgp-like activity in Strongylocentrotus droebachiensis and Leptasterias polaris coelomocytes and in S. droebachiensis vibratile cells, whereas the combination of RB with MK could highlight the presence of MRP-like proteins in S. droebachiensis and Cucumaria frondosa coelomocytes. MK is specific to the MRP family (Leier et al. 1994, Gekeler et al. 1995), although, with the present approach, it is not possible to determine which MRP is involved.

\section{Calcein incorporation}

The presence of MXR transporters was also confirmed in Leptasterias polaris coelomocytes and Strongylocentrotus droebachiensis vibratile cells using CAM as a model substrate. The inhibitor MK induced a significant decrease of CAM fluorescence in $L$. polaris coelomocytes and $S$. droebachiensis vibratile cells (Fig. 3B,C), as well as a similar trend in S. droebachiensis and $C$. frondosa coelomocytes, although high variability led to non-significant results (Fig. 3A,D). This MXR response could be due to the presence of MRP-like protein, MK being specific to this class of transporters. MK has previously been used to detect MRP-like protein transporters in many species (Gekeler et al. 1995, Wu et al. 2005, Bakos \& Homolya 2007, Zaja et al. 2008, Lüders et al. 2009). A decrease of fluorescence was generally not observed, but has previously been reported in mussel haemocytes using a combination of RB and Ver (Svensson et al. 2003). The results showing a fluorescence decrease could be explained by localization of the protein involved in the membranes of intracellular compartments. Based on tests with the lysosomal volume compartment in mussel haemocytes using the neutral red uptake assay, Svensson et al. (2003) hypothesized that Pgp was localized in the lysosomal membrane instead of in the cellular membrane. The presence of Pgp has also been found in the lysosomal compartment of specialized cells in the hepatopancreas of the crustacean Carcinus maenas (Köhler et al. 1998). This is in accordance with our data, since calcein fluorescence in L. polaris coelomocytes was localized in the intracellular granules, as observed by epifluorescence microscopy with and without MK (Fig. 4B,D), an indication of MRP-like proteins localized in the membranes of intracellular compartments. Actually, Pgp and MRP1 have been identified on the intracellular membrane in a human cancer cell line (Bour-Dill et al. 2000, Laochariyakul et al. 2003). The presence of MXR proteins inside the coelomocytes could also be due to the fundamental role of the coelomocytes, which engulf solid foreign materials by their cell membrane. Due to the high rate of plasma membrane turnover associated with the endocytosis process, the membrane protein turnover should be high as well. This may explain why Pgp and MRP pro- 
teins could be observed in the membranes of intracellular compartments.

Our results reveal that the MXR activity of coelomocytes induces a quite complex response toward model substrates and inhibitors. Not all observations reported here can be explained by this process, particularly when comparing the role of cells in which intracellular MDR was revealed. The coelomocytes (present paper) and haemocytes (Svensson et al. 2003) are indeed phagocytic cells, which was not the case for the cancer cell lines used by Bour-Dill et al. (2000) and Laochariyakul et al. (2003). MXR proteins could be present both in the plasma membrane and in an inner membrane of the cell, as illustrated by the scheme in Fig. 8. Following this scheme, calcein could be less accumulated inside the vesicles in the presence of the MRP inhibitor, but could still be pumped out of the cell by the Pgp-like transporters, causing fluorescence diminution as observed at the whole cell level by FCM.

\section{Response comparison}

This indirect measurement method has been used for a long time and is still used for the detection of Pgplike and MRP-like activities (Neyfakh 1988, Kerboeuf et al. 1999, Hamdoun et al. 2004, Lüders et al. 2009), as well as for the detection of MXR/MDR activity (Holland Toomey \& Epel 1993, Cornwall et al. 1995, Zaja et al. 2006, Caminada et al. 2008). The CsA and Ver are not as specific as first claimed $10 \mathrm{yr}$ ago. Even if they are still used as a potent Pgp inhibitor by some authors (Kagan et al. 2010, Wu et al. 2010), there are a few indications of their transport by MRP1 (Zaja et al. 2007, Kerr et al. 2010). In the present study, all combinations inducing fluorescence change have to be taken into account. Indeed, through dose-response curves (Fig. 5), there is strong indication of the presence of 2 different types of MXR activity in coelomocytes. The first MXR protein was revealed by a decrease of CAM fluorescence in a MK dose-dependent response in Strongylocentrotus droebachiensis and Leptasterias polaris (Fig. 5A). To our knowledge, no information on the interaction of MK and Pgp was previously available. MK is linked to the transport inhibition of the MRP family. As a recent example in invertebrates, the combination Flura 2/MK571 was used in crustacean tissues (Lüders et al. 2009) to highlight MRP-like protein activity. The second MXR protein in the present study was revealed by the increase of RB fluorescence in a CsA dose-dependent response in $S$. droebachiensis and L. polaris. Due to this contrary observation (increase instead of decrease for MK) and the fact that CsA is a potent Pgp inhibitor, the MXR activity observed here is probably due to the Pgp presence in coelomocytes. As a recent example in invertebrates, the combination of RB and CsA or Ver was used in gill tissue of the bivalve Unio pictorum (Zaja et al. 2006) to highlight Pgp-like protein.

A difference in substrate transport between Strongylocentrotus droebachiensis and Leptasterias polaris was observed, with L. polaris coelomocytes accumulating more fluorescence (CAM and $\mathrm{RB}$ ) than $S$. droebachiensis coelomocytes, despite similar cell size. This could be due to a lower MXR activity in $L$. polaris coelomocytes. Additional information, like time course re-

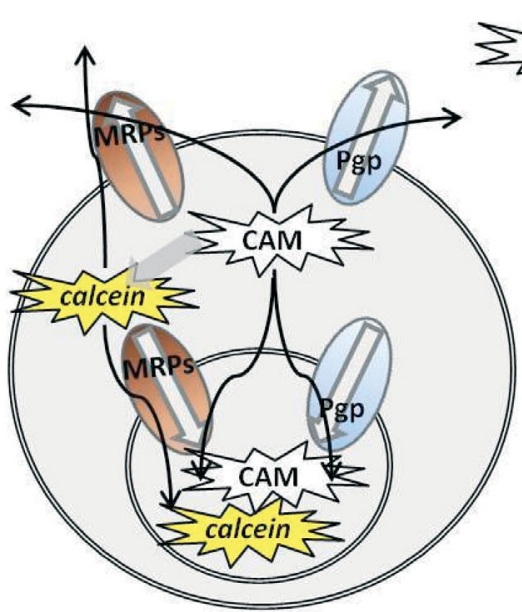

Fluorescence

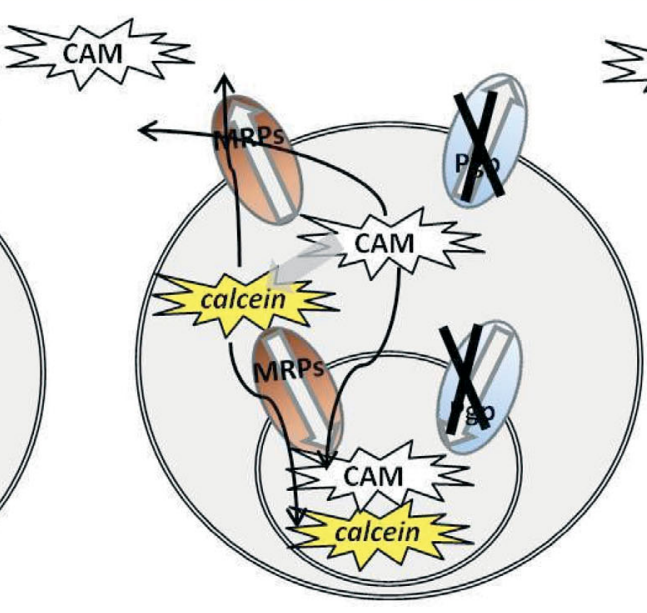

Same fluorescence

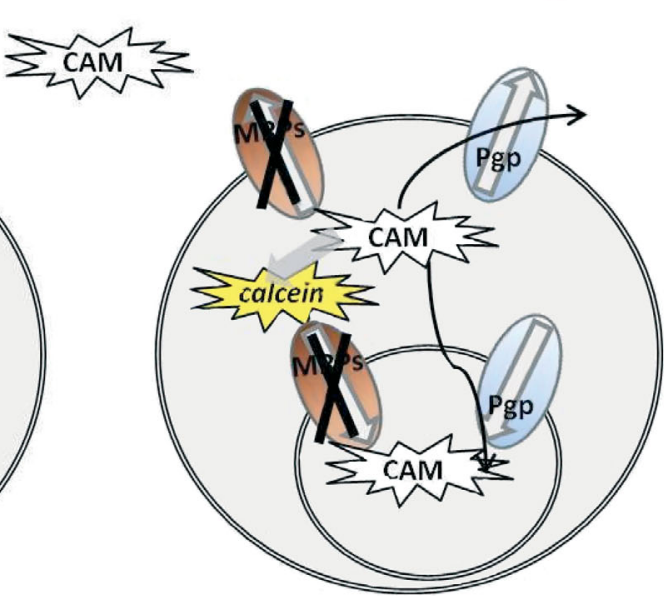

Decrease fluorescence

Fig. 8. Hypothetical scheme of P-glycoprotein (Pgp)-like and multidrug resistance-associated protein (MRP)-like distributions in coelomocytes. The presence of MK571 explains the decrease of calcein-AM (CAM) fluorescence 
sponses, would be necessary in a future MXR characterization of echinoderm coelomocytes.

\section{Western blot confirmation of MXR-like proteins in coelomocytes}

Results obtained by Western blot confirmed the presence of MXR-like proteins in echinoderm coelomocytes. Proteins reacting in Western blot (Figs. 6B \& 7B) were not necessarily the most abundant, as shown by silver staining (Figs. 6A \& 7A). The molecular weights of the proteins recognized by antibodies were about the same as described by other authors in invertebrates (Cornwall et al. 1995, Roepke et al. 2006). Nevertheless, no discrimination between MXRs could be achieved with this method, because C9 and C219 antibodies seemed to react with targeted proteins of the same molecular weight. Little information is available on MXR in echinoderms, and, to our knowledge, this is the first time these 2 antibodies have been used on the same extract of echinoderm coelomocytes. The molecular weights of Pgp and MRP are quite similar and change with species. For instance, a $135 \mathrm{kDa}$ Pgp was reported in Corbicula fluminea gills (Waldmann et al. 1995), while a $170 \mathrm{kDa}$ Pgp was reported in Mytilus edulis and M. californianus gills (Cornwall et al. 1995, Minier \& Moore 1996) and a 145 and a 220 kDa Pgp were found in M. galloprovincialis (Galgani et al. 1996), all determined by Western blot with the C219 antibody. Finally, other MRPs, with other molecular weights, were recognized by $\mathrm{C} 9$, although this is an antibody against MRP1, a $190 \mathrm{kDa}$ protein (Cole et al. 1992). The MRPs are indeed a big family of many homologues (Borst et al. 1999, Leslie et al. 2001). MRP members share preserved sections, particularly MRP1, MRP2, MRP3 and MRP6, for which most amino acids are shared in common (Leslie et al. 2001).

Glycosylation also plays a role in determination of the molecular weights of Pgp proteins (Kartner et al. 1985); Strongylocentrotus droebachiensis and Cucumaria frondosa coelomocytes contain glycoproteins, but their molecular weights could not be linked to the proteins reacting in our Western blot analysis (data not shown).

MS analysis did not allow us to confirm the presence of Pgp- or MRP-like proteins or to identify them by their structure, but this does not necessarily mean that the proteins are absent from coelomocytes. The amounts of MXR proteins in comparison with other proteins in band extracts were too low to be detected by MS analysis (S. Bourassa, Centre genomique de Québec, pers. comm.). In order to enable better discrimination of these proteins in MS and Western blot analyses, immunoprecipitation should be performed as a first step to purify the sample. Furthermore, other antibodies like MRPm6 or $\mathrm{M}_{2} \mathrm{I}-4$ (Sauerborn Klobucar et al. 2010) and other Western blot methods (utilizing preincubation of specific peptides according to the epitopes of antibodies) have to be tested in an attempt to discriminate the involved proteins. Finding MVP in the coelomocytes of Strongylocentrotus droebachiensis is new and unexpected. The sea urchin MVP showed a $20.4 \%$ similarity with the human Pgp recognized by Ab-C219, while only a $6.4 \%$ similarity was seen with the human MRP1 recognized by Ab-C9. Human MRP1 (Accession No. P33527), human Pgp (Accession No. P08183) and sea urchin MVP (Accession No. Q5EAJ7) amino acids sequence data were submitted to BLAST tools from the Swiss Institute of Bioinformatics (SwissProt) libraries to obtain and compare the above percents of similarity.

MVP is the main component of vaults - cytoplasmic megastructures located near the nucleus of the cell. MVP is highly preserved in evolution and has been found in most eukaryotic organisms (Kickhoefer et al. 1996, Steiner et al. 2006). MVP has been identified in the eggs and embryos of the sea urchin Lytechinus pictus (Hamill \& Suprenant 1997). The involvement of MVP in drug resistance has been proposed (Meschini et al. 2002, Steiner et al. 2006, Herlevsen et al. 2007), although this is still under debate (Mossink et al. 2002, van Zon et al. 2004). Finding MVP in Strongylocentrotus droebachiensis offers a new research perspective, as the role of MVP in the detoxification processes of coelomocytes has yet to be explored.

\section{CONCLUSIONS}

The coelomocytes in all 3 echinoderms showed MXR activity. This activity is tentatively attributed to a Pgplike transporter in Strongylocentrotus droebachiensis coelomocytes and vibratile cells and in Leptasterias polaris coelomocytes, as the $\mathrm{RB}+\mathrm{CsA}$ and $\mathrm{RB}+\mathrm{Ver}$ combinations led to a change in RB accumulation. Another type of MXR activity was observed with the CAM+MK combination. This could be attributed to the presence of MRP-like transporters in Cucumaria frondosa, $S$. droebachiensis and L. polaris coelomocytes.

The results of the present study have increased our knowledge on coelomocyte physiology and on the differences between echinoderm species. Through the use of anti-Pgp antibodies and MS, a MVP has been identified in Strongylocentratus droebachiensis coelomocytes (including vibratile cells). This raises the question about the link between MVP and xenobiotic resistance. Further studies are necessary in order to learn more about the physiology of coelomocytes and their MXR activity. 
Acknowledgements. This research was supported by an operating grant (É.P.) from the Natural Sciences and Engineering Research Council of Canada, a student grant (É.D.) from the Institut des Sciences de la mer de Rimouski (ISMER-UQAR) and by grants from both the Ministère de l'Agriculture, des Pêcheries et de l'Alimentation (Quebec, Canada) and La Fondation Communautaire Gaspésie-Les-Iles (Quebec, Canada). The authors thank I. Desbiens (ISMER-UQAR), D. Lavallée (ISMER-UQAR), J. Thibodeau (UQAR-MAPAQ), R. SaintLouis (ISMER-UQAR) and K. Békri (NRCC-Institute for Marine Biosciences) for their assistance in the course of this project. Many thanks to the anonymous reviewers for their valuable comments and suggestions during the reviewing process. All experiments conducted in the course of this work complied with the regulations set down by the Canadian Council on Animal Care. The authors declare that they have no conflicts of interest regarding the contents of this paper.

\section{LITERATURE CITED}

Ambudkar SV, Dey S, Hrycyna CA, Ramachandra M, Pastan I, Gottesman MM (1999) Biochemical, cellular, and pharmacological aspects of the multidrug transporter. Annu Rev Pharmacol Toxicol 39:361-398

Bakos É, Homolya L (2007) Portrait of multifaceted transporter, the multidrug resistance-associated protein 1 (MRP1/ABCC1). Eur J Appl Physiol 453:621-641

Bard SM (2000) Multixeniobiotic resistance as a cellular defense mechanism in aquatic organisms. Aquat Toxicol 48:357-389

Békri K, Pelletier É (2004) Trophic transfer and in vivo immunotoxicological effects of tributyltin (TBT) in polar seastar Leptasterias polaris. Aquat Toxicol 66:39-53

Biedler JL, Riehm H, Peterson RH, Spengler BA (1975) Membrane-mediated drug resistance and phenotypic reversion to normal growth behavior of Chinese hamster cells. J Natl Cancer Inst 55:671-680

Borst P, Evers R, Kool M, Wijnholds J (1999) The multidrug resistance protein family. Biochim Biophys Acta 1461: 347-357

Bour-Dill C, Gramain MP, Merlin JL, Marchal S, Guillemin F (2000) Determination of intracellular organelles implicated in daunaurubicin cytoplasmic sequestration in multi-drug resistance MCF-7 cells using fluorescence microscopy image analysis. Cytometry 39:16-25

Caminada D, Zaja R, Smital T, Fent K (2008) Human pharmaceuticals modulate P-gp1 (ABCB1) transport activity in the fish cell line PLHC-1. Aquat Toxicol 90:214-222

Chia FS, Xing J (1996) Echinoderm coelomocytes. Zool Stud 35:231-254

> Cole SPC, Bhardwaj G, Gerlach J, Mackie J and others (1992) Overexpression of a transporter gene in a multidrugresistant human lung cancer cell line. Science 258: 1650-1654

Conover WJ (1980) Practical nonparametric statistics. Wiley \& Sons, New York, NY

Cornwall R, Holland Toomey B, Bard SM, Bacon C, Jarman WM, Epel D (1995) Characterization of multixenobiotic/ multidrug transport in the gills of the mussel Mytilus californianus and identification of environmental substrates. Aquat Toxicol 31:277-296

> Daoud R, Kast C, Gros P, Georges E (2000) Rhodamine 123 binds to multiple sites in the Multidrug Resistance Protein (MRP1). Biochemistry 39:15344-15352

$>$ Dressen TD, Johnson DH, Henikoff S (1988) The brown protein of Drosophila melanogaster is similar to the white pro- tein and to components of active transport complexes. Mol Cell Biol 8:5206-5215

Dudler R, Hertig C (1992) Structure of an mdr-like gene from Arabidopsis thaliania. Evolutionary implications. J Biol Chem 267:5882-5888

Edds KT (1993) Cell biology of echinoid coelomocytes. I. Diversity and characterization of cell types. J Invertebr Pathol 61:173-178

Epel D (1998) Use of multidrug transporters as first lines of defense against toxins in aquatic organisms. Comp Biochem Physiol Part A Mol Integr Physiol 120:23-28

Essodaïgui M, Broxterman HJ, Garnier-Suillerot A (1998) Kinetic analysis of calcein and calcein-acetoxymethylester efflux mediated by the multidrug resistance protein and P-glycoprotein. Biochemistry 37:2243-2250

- Eytan GD, Regev R, Oren G, Assaraf YG (1996) The role of passive transbilayer drug movement in multidrug resistance and its modulation. J Biol Chem 271:3163-3171

Foxwell BM, Mackie A, Ling V, Ryffel B (1989) Identification of the multidrug resistance-related P-glycoprotein as a cyclosporine binding protein. Mol Pharmacol 36:543-546

Galgani F, Cornwall R, Holland Toomey B, Epel DD (1996) Interaction of environmental xenobiotics with a multixenobiotics defense mechanism in the bay mussel Mytilus galloprovincialis from the coast of California. Environ Toxicol Chem 16:325-331

Gekeler V, Ise W, Sanders KH, Ulrich WR, Beck J (1995) The leukotriene LTD4 receptor antagonist MK571 specifically modulates MRP associated multidrug resistance. Biochem Biophys Res Commun 208:345-352

> Haimeur A, Conseil G, Deeley RG, Cole SPC (2004) The MRP-related and BCRP/ABCG2 multidrug resistance proteins: biology, substrate specificity and regulation. Curr Drug Metab 5:21-53

Hamdoun AM, Cherr GN, Roepke TA, Epel D (2004) Activation of multidrug efflux transporter activity at fertilization in sea urchin embryos (Strongylocentrotus purpuratus). Dev Biol 276:452-462

Hamill DR, Suprenant KA (1997) Characterization of the sea urchin major vault protein: a possible role for vault ribonucleoprotein particles in nucleocytoplasmic transport. Dev Biol 190:117-128

> Havlis J, Thomas H, Sebela M, Shevchenko A (2003) Fastresponse proteomics by accelerated in-gel digestion of proteins. Anal Chem 75:1300-1306

> Hemmer MJ, Courtney LA, Ortego LS (1995) Immunohistochemical detection of P-glycoprotein in teleost tissues using mammalian polyclonal and monoclonal antibodies. J Exp Zool 272:69-77

> Herlevsen M, Oxford G, Owens CR, Conaway M, Theodorescu D (2007) Depletion of major vault protein increases doxorubicin sensitivity and nuclear accumulation and disrupts its sequestration in lysosomes. Mol Cancer Ther 6: 1804-1813

> Holland Toomey B, Epel D (1993) Multixenobiotic resistance in Urechis caupo embryos: protection from environmental toxins. Biol Bull 185:355-364

Hollo Z, Homolya L, Hegedfis T, Sarkadi B (1996) Transport properties of the multidrug resistance-associated protein (MRP) in human tumour cells. FEBS Lett 383:99-104

Johnstone RW, Ruefli AA, Smyth MJ (2000) Multiple physiological functions for multidrug transporter P-glycoprotein? Trends Biochem Sci 25:1-6

> Kagan L, Dreifinger T, Mager DE, Hoffman A (2010) Role of P-glycoprotein in region-specific gastrointestinal absorption of talinolol in rats. Drug Metab Dispos 38:1560-1566 Kaneshiro K, Karp RD (1980) The ultrastructure of coelomo- 
cytes of the sea star Dermasterias imbricata. Biol Bull 159: 295-310

Kartner N, Evernden-Porelle D, Bradley G, Ling V (1985) Detection of P-glycoprotein in multidrug-resistant cell lines by monoclonal antibodies. Nature 31-:820-823

Kerboeuf D, Chambrier P, Le Vern Y, Aycardi J (1999) Flow cytometry analysis of drug transport mechanisms in Haemonchus contortus susceptible or resistant to anthelmintics. Parasitol Res 85:118-123

Kerr ID, Jones PM, George AM (2010) Multidrug efflux pumps: the structures of prokaryotic ATP-binding cassette transporter efflux pumps and implications for our understanding of eukaryotic P-glycoproteins and homologues. FEBS J 277:550-563

Kessel D, Botteril V, Wodinsky I (1968) Uptake and retention of daunomycin by mouse leukemic cells as factors in drug response. Cancer Res 28:938-941

Kickhoefer VA, Vasu SK, Rome LH (1996) Vaults are the answer, what is the question? Trends Cell Biol 6:174-178

Köhler A, Lauritzen B, Jansen D, Battcher P, Teguliwa L, Kriiner G, Broeg K (1998) Detection of P-glycoprotein mediated MDR/MXR in Carcinus maenas hepatopancreas by immuno-gold-silver labeling. Mar Environ Res 46:411-418

Laochariyakul P, Ponglikitmongkol M, Mankhetkorn S (2003) Functional study of intracellular P-gp and MRP1-mediated pumping of free cytosolic pirarubicin into acidic organelles in intrinsec resistant SiHa cells. Can J Physiol Pharmacol 81:790-799

> Leier I, Buchholz U, Cole SPC, Deeley RG, Keppler D (1994) The MRP gene encodes an ATP-dependent export pump for leukotriene $\mathrm{C} 4$ and structurally related conjugates. J Biol Chem 269:27807-27810

> Leslie EM, Deeley RG, Cole SPC (2001) Toxicological relevance of the multidrug resistance protein 1, MRP1 (ABCC1) and related transporters. Toxicology 167:3-23

> Lindl T, Lewandowski B, Schreyögg S, Stäudte A (2005) An evaluation of the in vitro cytotoxicities of 50 chemicals by using an electrical current exclusion method versus the neutral red uptake and MTT assays. Altern Lab Anim 33: 591-601

Litman T, Druley TE, Stein WD, Bates SE (2001) From MDR to MXR: new understanding of multidrug resistance systems, their properties and clinical significance. Cell Mol Life Sci 58:931-959

Lüders AK, Saborowski R, Bickmeyer U (2009) Inhibition of multidrug/xenobiotic resistance transporter by MK571 improves dye (Flura2) accumulation in crustacean tissues from lobster, shrimp and isopod. Comp Biochem Physiol 150 (Part C):368-371

Marin M, Legros H, Poret A, Leboulenger F, Le Foll F (2004) Cell responses to xenobiotics: comparison of MCF7 multidrug- and mussel blood cell multi-xenobiotic-defense mechanisms. Mar Environ Res 58:209-213

> Meschini S, Marra M, Calcabrini A, Monti E, Gariboldi M, Dolfini E, Arancia G (2002) Role of the lung resistancerelated protein (LRP) in the drug sensitivity of cultured tumor cells. Toxicol In Vitro 16:389-398

> Minier C, Moore MN (1996) Rhodamine B accumulation and MXR protein expression in mussel blood cells: effects of exposure to vincristine. Mar Ecol Prog Ser 142:165-173

> Minier C, Eufemia N, Epel D (1999) The multi-xenobiotic resistance phenotype as a tool to biomonitor the environment. Biomarkers 4:442-454

Mossink MH, van Zon A, Fränzel-Luiten E, Schoester M and others (2002) Disruption of the murine major vault protein (MVP/LRP) gene does not induce hypersensitivity to cyto- statics. Cancer Res 62:7298-7304

Müller M, Bakos E, Welker E, Varadi A and others (1996) Altered drug-stimulated ATPase activity in mutants of the human multidrug resistance protein. J Biol Chem 271: 1877-1883

Müller WEG, Steffen R, Rinkevich B, Matranga V, Kurelec B (1996) The multixenobiotic resistance mechanism in the marine sponge Suberites domuncula: its potential applicability for the evaluation of environmental pollution by toxic compounds. Mar Biol 125:165-170

- Neyfakh AA (1988) Use of fluorescent dyes as molecular probes for the study of multidrug resistance. Exp Cell Res 174:168-176

> Noble PB (1970) Coelomocyte aggregation in Cucumaria frondosa: effect of ethylenediaminetetraacetate, adenosine, and adenosine nucleotides. Biol Bull 139:549-556

Reungpatthanaphong $\mathrm{P}$, Dechsupa S, Meesungnoen J, Loetchutinat C, Mankhetkorn S (2003) Rhodamine B as a mitochondrial probe for measurement and mitochondrial membrane potential in drug-sensitive and -resistant cells. J Biochem Biophys Methods 57:1-16

Roepke TA, Hamdoun AM, Cherr GN (2006) Increase in multidrug transport activity is associated with oocyte maturation in sea stars. Dev Growth Differ 48:559-573

Romsicki Y, Sharom FJ (1999) The membrane lipid environment modulates drug interactions with the P-glycoprotein multidrug transporter. Biochemistry 38:6887-6896

Saeki T, Ueda K, Tanigawara Y, Hori R, Komano T (1993) Human P-glycoprotein transport cyclosporin A and FK506. J Biol Chem 268:6077-6080

Sauerborn Klobucar R, Zaja R, Franjevic D, Brozovic A, Smital T (2010) Presence of ecotoxicologically relevant Pgp and MRP transcripts and proteins in cyprinid fish. Arh Hig Rada Toksikol 61:175-182

Scherer C, Wiltshire K, Bickmeyer U (2008) Inhibition of multidrug resistance transporters in the diatom Thalassiosira rotula facilitates dye staining. Plant Physiol Biochem 46: 100-103

- Shevchenko A, Wilm M, Vorm O, Mann M (1996) Mass spectrometric sequencing of proteins from silver-stained polyacrylamide gels. Anal Chem 68:850-858

Smital T, Luckenbach T, Sauerborn R, Hamdoun AM, Vega RL, Epel D (2004) Emerging contaminants-pesticides, PPCPs, microbial degradation products and natural substances as inhibitors of multixenobiotic defense in aquatic organisms. Mutat Res 552:101-117

Smith AB (2008) Deuterostomes in a twist: the origins of a radical new body plan. Evol Dev 10:493-503

Steiner E, Holzmann K, Elbling L, Micksche M, Berger W (2006) Cellular functions of vaults and their involvement in multidrug resistance. Curr Drug Targets 7:923-934

Supino R (1995) MTT assays. In: O'Hare S, Atterwill CK (eds) Methods in molecular biology: in vitro toxicity testing protocols. Humana Press, Totowa, NJ, p 137-149

Svensson S, Särngren A, Förlin L (2003) Mussel blood cells, resistant to the cytotoxic effects of okadaic acid, do not express cell membrane p-glycoprotein activity (multixenobiotic resistance). Aquat Toxicol 65:27-37

Tamai I, Safa AR (1990) Competitive interaction of cyclosporins with the vinca alkaloid-binding site of P-glycoprotein in multidrug-resistant cells. J Biochem Biophys Methods 265:16509-16513

> Twentyman PR, Luscombe M (1987) A study of some variables in a tetrazolium dye (MTT) based assay for cell growth and chemosensitivity. Br J Cancer 56:279-285

> van Zon A, Mossink MH, Schoester M, Scheper RJ, Sonneveld P, Wiemer EAC (2004) Efflux kinetics and intracellu- 
lar distribution of daunorubicin are not affected by major vault protein/lung resistance-related protein (vault) expression. Cancer Res 64:4887-4892

Waldmann P, Pivcevic B, Müller WEG, Zahn RK, Kurelec B (1995) Increased genotoxicity of acetylaminofluorene by modulators of multixenobiotic resistance mechanism: studies with the fresh water clam Corbicula fluminea. Mutat Res 342:113-123

> Willingham MC, Cornwell MM, Cardarelli CO, Gottesman MM, Pastan I (1986) Single cell analysis of daunomycin uptake and efflux in multidrug-resistant and -sensitive KB cells: effects of verapamil and other drugs. Cancer Res 46: 5941-5946

Wu CP, Klokouzas A, Hladky SB, Ambudkar SV, Barrand MA (2005) Interactions of mefloquine with $\mathrm{ABC}$ proteins, MRP1 (ABCC1) and MRP4 (ABCC4) that are present in human red cell membranes. Biochem Pharmacol 70: 500-510

Wu YT, Kao YL, Lin LC, Tsai TH (2010) Effects of a P-glyco-

Editorial responsibility: Hans Heinrich Janssen, Oldendorf/Luhe, Germany protein modulator on the pharmacokinetics and distribution of free levobupivacaine and bupivacaine in rats. Int $\mathrm{J}$ Pharm 396:127-133

Xing K, Yang HS, Chen MY (2008) Morphological and ultrastructural characterization of the coelomocytes in Apostichopus japonicus. Aquat Biol 2:85-92

Zaja R, Klobucar GIV, Sauerborn Klobucar R, Hackenberger BK, Smital T (2006) Haemolymph as compartment for efficient and non-destructive determination of P-glycoprotein (Pgp) mediated MXR activity in bivalves. Comp Biochem Physiol C 143:103-112

Zaja R, Sauerborn Klobucar R, Smital T (2007) Detection and functional characterization of Pgp1 (ABCB1) and MRP3 (ABCC3) efflux transporters in the PLHC-1 fish hepatoma cell line. Aquat Toxicol 8:365-376

Zaja R, Caminada D, Lončar J, Fent K, Smital T (2008) Development and characterization of P-glycoprotein 1 (Pgp1, ABCB1)-mediated doxorubicin-resistant PLHC-1 hepatoma fish cell line. Toxicol Appl Pharmacol 227:207-218

Submitted: July 26, 2010; Accepted: February 2, 2011

Proofs received from author(s): March 27, 2011 